\title{
ANALISIS MUATAN NILAI KARAKTER DALAM BUKU TEKS PENDIDIKAN PANCASILA DAN KEWARGANEGARAAN SMP KELAS VIII
}

\author{
Titik Haryati dan Nor Khoiriyah \\ Program Studi PPKn Universitas PGRI Semarang \\ email: Ria_civicus@yahoo.com
}

\begin{abstract}
Abstrak: Tujuan penelitian ini adalah untuk menganalisis muatan nilai-nilai karakter dalam buku teks Pendidikan Pancasila dan Kewarganegaraan SMP Kelas VIII. Penelitian ini menggunakan metode analisis konten dengan pendekatan kualitatif. Sumber data penelitian adalah buku teks Pendidikan Pancasila dan Kewarganegaraan SMP kelas VIII. Unit analisis dalam penelitian ini adalah muatan nilai karakter yang tersebar dalam semua bagian buku. Pengumpulan data dengan analisis secara cermat dan pencatatan tentang muatan nilai karakter yang ada dalam buku teks. Pemeriksaan keabsahan data berdasarkan validitas semantik dan reliabilitasnya adalah reliabilitas interrater. Hasil penelitian menunjukkan bahwa muatan nilai-nilai karakter kebangsaan yang dikembangkan oleh Kemendikbud dalam buku teks Pendidikan Pancasila dan Kewarganegaraan SMP kelas VIII disajikan pada tiga bagian yaitu (1) pada bagian pendahuluan terdiri atas kalimat motivasi, ilustrasi gambar, (2) bagian inti terdiri atas uraian materi pelajaran, tugas individu, dan tugas kelompok, dan (3) bagian penutup terdiri atas refleksi, uji kompetensi, penilaian afektif, dan praktik kewarganegaraan.
\end{abstract}

Kata Kunci: nilai karakter, buku teks, Pendidikan Pancasila dan Kewarganegaraan

\section{THE ANALYSIS OF CHARACTER VALUES IN PANCASILA AND CIVICS EDUCATION TEXTBOOK FOR VIII GRADE JUNIOR HIGH SCHOOL}

\begin{abstract}
The purpose of this study is to analyze the content of character values in Pancasila and Civics Education Textbook for VIII grade Junior High School. The research method uses content analysis with qualitative approach. The sources of the data research are the Pancasila and Civics Education textbooks for VIII grade Junior High School. The unit of analysis in this study is the content of the character values spread in all parts of the book. While the data collection using a careful analysis and recording the content of the character values in the text book. The validity of the data is based on semantic validity, while the reliability is the interrater reliability. The result of the research shows that the content of the Nationality character values which have been developed by the Ministry of National Education and Culture in Pancasila and Civics Education textbook for VIII grade Junior High School is presented in three parts: (1) The introduction consists of motivation sentences, picture illustration; (2) the core section consists of a description of the subject matter, individual tasks, and group tasks; (3) the closing section consists of reflections, competency tests, affective judgments, and civic practices.
\end{abstract}

Keywords: Character value, textbook, Pancasila and Civics Education. 


\section{PENDAHULUAN}

Pendidikan merupakan usaha sadar yang ditempuh oleh manusia dalam rangka memperoleh ilmu yang kemudian dijadikan sebagai dasar untuk bersikap dan berperilaku. Oleh karena itu, pendidikan merupakan salah satu proses pembentukan karakter manusia. Hal ini mengandung makna bahwa proses pendidikan akan menghasilkan sikap dan perilaku yang akhirnya menjadi watak, kepribadian, atau karakternya dalam mencapai manusi seutuhnya. Seiring dengan perkembangan ipteks, pendidikan mengalami proses dinamis yang harus menyesuaikan dengan situasi dan kondisi yang ada. Namun, dalam perjalanannya pendidikan telah mengalami perubahan kurikulum dan inovasi dalam rangka mencapai tujuan Pendidikan Nasional yang tertuang di dalam Undang-Undang Nomor 20 Tahun 2003 tentang Sistem Pendidikan Nasional. Salah satu bentuk inovasi pendidikan yang telah dilakukan adalah penanaman pendidikan karakter kebangsaan melalui berbagai proses pendidikan. Lickona (1991: 51) mengemukakan bahwa pendidikan karakter seharusnya membawa peserta didik pada pengenalan nilai secara kognitif (moral knowing), penghayatan nilai secara afektif (moral feeling), dan akhirnya ke pengamalan nilai secara nyata (moral action). Dari pernyataan Lickona tersebut, maka semua mata pelajaran di sekolah harus bermuatan nilai-nilai karakter yang akan membawa peserta didik menjadi manusi berkarakter.

Penataan pendidikan nasional Indonesia dimulai dengan menempatkan kembali karakter sebagai dimensi dalam pendidikan nasional yang berdampingan dengan intelektualitas yang tercermin dalam kompetensi. Pada masa pemerintahan Presiden Joko Widodo saat ini telah dirumuskan program nawacita, salah satu programnya adalah memperkuat pendidikan karakter bangsa sebagai bagian dari Gerakan Nasional
Revolusi Mental (GNRM) dalam bidang pendidikan. Lebih lanjut Arie Budhiman (2017) menyampaikan dalam sosialisasi gerakan penguatan pendidikan karakter bahwa karakter sebagai poros pendidikan melalui program nawacita salah satunya dilakukan dengan membangun Pendidikan Kewarganegaraan (sejarah pembentukan bangsa, nilai-nilai patriotisme dan cinta tanah air, semangat bela negara, dan budi pekerti). Hubungan antara Pendidikan Kewarganegaraan dan pendidikan karakter tidak dapat dipisahkan, Nur Silay (2014: 5) mengemukakan bahwa keduanya membahas berkaitan dengan moral. Pendidikan karakter sebagai arus pendidikan komprehensif mencakup Pendidikan Kewarganegaraan (Howard, et al., 2014). Hal ini mengandung makna bahwa Pendidikan Kewarganegaraan sebagai mata pelajaran di sekolah harus mampu mengintegrasikan pendidikan karakter secara utuh dalam kurikuler.

Salah satu bentuk integrasi pendidikan karakter dalam Pendidikan Kewarganegaraan dilakukan melalui internalisasi nilai-nilai karakter dalam buku teks mata pelajaran Pendidikan Kewarganegaraan. Namun, selama ini buku teks yang telah banyak digunakan oleh guru maupun peserta didik di sekolah belum secara menyeluruh memuat nilai-nilai karakter Kebangsaan. Oleh karena itu, Marzuki (2012: 41) menyatakan bahwa perlu adanya adaptasi pendidikan karakter dalam buku ajar yang akan digunakan oleh guru pada proses pembelajaran. Adaptasi yang paling mungkin dilaksanakan oleh guru adalah dengan cara menambah kegiatan pembelajaran yang sekaligus dapat mengembangkan karakter. Cara lainnya adalah dengan mengadaptasi atau mengubah kegiatan belajar pada buku ajar yang dipakai. Adaptasi dapat dilakukan dengan merevisi substansi pembelajarannya.

Sejalan diberlakukannya kurikulum 2013 Kemendikbud telah menerbitkan buku teks Pendidikan 
Pancasila dan Kewarganegaraan SMP/MTs kelas VIII sebagai buku pegangan guru dan buku pegangan siswa dalam proses pembelajaran. Buku teks ini telah berusaha untuk memenuhi kriteria buku teks yang diamanatkan pemerintah, yaitu memuat nilai-nilai karakter kebangsaan yang harus ditanamkan kepada peserta didik dengan menyesuaikan materi pelajaran pada setiap babnya. Dalam Peraturan Menteri Pendidikan Nasional Nomor 11 tahun 2005 tentang buku teks pelajaran menjelaskan bahwa buku teks adalah buku acuan wajib untuk digunakan di sekolah yang memuat materi pembelajaran dalam rangka peningkatan keimanan dan ketakwaan, budi pekerti dan kepribadian, kemampuan penguasaan ilmu pengetahuan dan teknologi, kepekaan dan kemampuan estetis, serta potensi fisik dan kesehatan yang disusun berdasarkan standar nasional pendidikan. Dari pengertian tersebut, secara tidak langsung Pemerintah telah mengamanatkan bahwa buku teks selain memuat materi pembelajaran juga harus memuat nilainilai karakter dalam rangka meningkatkan budi pekerti dan kepribadian peserta didik sebagai generasi bangsa.

Dalam rangka menanamkan nilainilai karakter melalui buku ajar, Muhammad Yaumi (2014:141) menyatakan bahwa strategi pengembangan buku ajar berbasis pendidikan karakter merupakan cara penyusunan dan pembuatan buku ajar dengan mengintegrasikan nilai-nilai karakter dalam buku ajar dan aktivitas pembelajaran. Lebih lanjut Bank and Bank (1997) menjelaskan strategi integrasi nilai-nilai karakter dilakukan melalui lima dimensi, yaitu

1. Integrasi konten, merujuk pada bangunan kurikulum yang mengintegrasikan contoh-contoh dan nilai-nilai budaya dan karakter untuk mengilustrasikan konsep inti, prinsip, generalisasi, dan teori dalam mata pelajaran.

2. Integrasi konstruksi pengetahuan, berhubungan dengan bagaimana nilai-nilai budaya dan karakter yang dianut oleh kelompok orang memengaruhi cara pandang, pendapat, dan berbuat. Pengetahuan dikonstruksi melalui proses pembelajaran.

3. Pengurangan prasangka, yaitu membangun sikap positif di antara peserta didik yang dilakukan oleh pendidik dalam proses pembelajaran.

4. Pedagogik yang setara, yaitu pendidik dalam mengangkat persoalan atau isu selalu berhubungan dengan membangun karakter peserta didik.

5. Pemberdayaan budaya sekolah, yaitu nilai-nilai budaya dan karakter dikembangkan melalui kepribadian peserta didik.

Dari kelima strategi yang dikemukakan oleh Bank and Bank, Muhammad Yaumi (2014) meringkas menjadi tiga aspek penting, yaitu: (1) integrasi konten, meliputi lima langkah, yaitu memilih topik, menentukan nilai karakter, membuat contoh, evaluasi, dan revisi; (2) integrasi nilai-nilai karakter dalam aktivitas pembelajaran, dilakukan melalui enam tahap, yaitu analisis, penentuan nilai dan karakter, memilih tugas, memilih metode, menentukan media, dan melakukan pengujian dan revisi; dan (3) pemberdayaan budaya sekolah, yaitu dibangun melalui kegiatan ekstrakurikuler dan organisasi sekolah.

Telah banyak dilakukan penelitian terkait dengan muatan nilai-nilai karakter dalam buku teks, misalnya Sasi Mardikarini dan Suwarjo (2016) telah melakukan penelitian tentang "Analisis Muatan Nilai-Nilai Karakter Pada Buku Teks Kurikulum 2013 Pegangan Guru dan Pegangan Siswa". Normawati (2015) telah melakukan penelitian tentang "Nilai Pendidikan Karakter Dalam Buku Teks Pelajaran Bahasa 
Indonesia SMP di Daerah Istimewa Yogyakarta.

Berkaitan dengan hubungan

Pendidikan Kewarganegaraan dan pendidikan karakter yang telah dijelaskan di atas, penelitian ini bertujuan untuk menganalisis nilai-nilai karakter dalam buku teks mata pelajaran Pendidikan Pancasila dan Kewarganegaraan kelas VIII. Adapun nilai-nilai karakter yang dimaksud adalah nilai karakter yang dikembangkan oleh gerakan Penguatan Pendidikan Karakter (PPK) yang meliputi religius, nasionalis, mandiri, gotong royong, dan integritas. Kelima nilai tersebut menjadi nilai dasar dalam revolusi karakter bangsa dan gerakan revolusi mental yang telah ditetapkan dalam Konsep dan Pedoman Penguatan Pendidikan Karakter oleh Kementerian Pendidikan dan Kebudayaan Republik Indonesia tahun 2017. Selain dari lima nilai tersebut, analisis muatan nilai karakter juga didasarkan pada delapan belas nilai yang dikembangkan dalam Pedoman Pengembangan Pendidikan Budaya dan Karakter Bangsa (2010:9-10), yaitu religius, jujur, toleransi, disiplin, kerja keras, kreatif, mandiri, demokratis, rasa ingin tahu, semangat Kebangsaan, cinta tanah air, menghargai prestasi, bersahabat/komunikatif, cinta damai, gemar membaca, peduli lingkungan.

\section{METODE}

Penelitian ini menggunakan
metode analisis konten $r$ dengan
pendekatan kualitatif. Penelitian analisis
konten merupakan penelitian untuk
membuat simpulan yang dapat
direplikasi dari teks (atau materi penting
lainnya) dalam konteks penggunaannya
(Krippendorff, 2004: 18). Analisis
konten yang dimaksud adalah analisis
dokumen buku ajar PPKn SMP berjudul
"Pendidikan Pancasila ran Kewarganegaraan SMP/MTs kelas VIII" terbitan Kementrian Pendidikan dan Kebudayaan Republik Indonesia tahun 2014. Adapun bagian yang dianalisis adalah muatan nilai karakter dalam buku ajar tersebut. Penelitian ini dilaksanakan pada bulan Januari sampai dengan Maret 2017.

Data dalam penelitian ini diperoleh dengan menggunakan sampling dengan teknik nonrandom sampling dan purposive sampling. Adapun sumber data sampling-nya adalah buku teks PPKn SMP yang berjudul "Pendidikan Pancasila dan Kewarganegaraan SMP/MTs kelas VIII" terbitan Kementrian Pendidikan dan Kebudayaan Republik Indonesia tahun 2014. Buku ini dijadikan sampling dalam penelitian karena telah dijadikan sebagai buku wajib pegangan guru dan pegangan siswa dalam Kurikulum 2013. Unit analisis dalam penelitian ini adalah muatan nilai karakter yang tersebar dalam semua bagian buku. Sedang pengumpulan data dengan cara analisis secara cermat dan pencatatan tentang muatan nilai karakter yang ada dalam buku teks. Adapun instrumennya adalah peneliti sendiri.

Keabsahan data dalam penelitian ini berdasarkan validitas dan reliabilitas. Validitas data menggunakan validitas semantik yaitu dengan cara mengamati data-data pada bagian pendahuluan terdiri dari kalimat motivasi dan ilustrasi gambar serta tujuan dan ruang lingkup pembelajaran. Bagian inti terdiri atas uraian materi pelajaran, tugas individu, dan tugas kelompok. Bagian penutup terdiri atas refleksi, uji kompetensi, penilaian afektif, dan praktik kewarganegaraan. Sedangkan reliabilitas yang digunakan dalam penelitian ini adalah reliabilitas intrarater, yaitu dengan cara membaca dan mengkaji ulang untuk mendapatkan data yang konsisten.

\section{HASIL DAN PEMBAHASAN Hasil Penelitian}

Muatan nilai-nilai karakter dianalisis dalam buku ajar Pendidikan Pancasila dan Kewarganegaraan SMP Kelas VIII terbitan Kementrian 
Pendidikan dan Kebudayaan cetakan ke1 tahun 2014 disusun dengan huruf Minion Pro, 11 pt. Jumlah halaman 170 dengan ukuran panjang kertas 25 x 14 $\mathrm{cm}$. Kontributor naskah: Salikun dan Lukman Surya Saputra, Penelaah: Muhammad Halimi dan Nasiwan. Penyelia penerbitan: Pusat Kurikulum dan Perbukuan, Balitbang, Kemendikbud. Kata pengantar dari Menteri Pendidikan dan Kebudayaan yaitu Muhammad Nuh. Buku ajar ini terdiri atas tujuh bab yang dibagi dalam semester 1 dan semester 2 .

Pada semester satu buku teks PPKn meliputi Bab I tentang "Merajut Manusia dan Masyarakat Berdasarkan Pancasila". Bab ini terdiri atas 3 subbab yaitu: (1) Pancasila sebagai Dasar Negara dan Pandangan Hidup Bangsa, (2) Nilai-nilai Pancasila sebagai Dasar Negara dan Pandangan Hidup Bangsa, (3) Membiasakan Perilaku sesuai Nilainilai Pancasila dalam Berbagai Kehidupan. Bab II tentang "Menyemai Kesadaran Konstitusi dalam Kehidupan Bernegara", yang terdiri atas 3 subbab yaitu: (1) Lembaga Negara sesuai dengan UUD Negara Republik Indonesia Tahun 1945, (2) Memahami Hubungan Antarlembaga Negara sesuai dengan UUD Negara Republik Indonesia Tahun 1945, dan (3) Sikap Positif terhadap Sistem Pemerintahan Indonesia. Bab III tentang "Disiplin itu Indah", yang terdiri atas 3 subbab yaitu: (1) Makna Tata Urutan Peraturan Perundang-Undangan di Indonesia, (2) Proses Pembuatan Peraturan Perundang-undangan Indonesia, dan (3) Ketaatan Terhadap Peraturan Perundang-undangan. Bab IV tentang "Menjelajah Masyarakat Indonesia, yang terdiri atas 3 subbab yaitu: (1) Norma dan Kebiasaan Antardaerah di Indonesia, (2) Arti Penting Keberagaman Konteks Norma dan Kebiasaan Antardaerah di Indonesia, (3) Menghargai Norma dan Kebiasaan Antardaerah di Indonesia.

Pada Semester dua buku teks PPKn meliputi Bab V tentang "Kita
Semua Sederajat dan Bersaudara". Bab ini terdiri atas 3 subbab, yaitu: (1) Hakikat Hak Asasi Manusia, (2) Memahami Jaminan Perlindungan Hak dan Kewajiban ASasi Manusia dalam UUD Negara Republik Indonesia Tahun 1945, dan (3) Menghargai dan Melaksanakan Hak dan Kewajiban Asasi Manusia sesuai UUD Negara Republik Indonesia Tahun 1945. Bab VI tentang "Pemuda Penentu Masa Depan Indonesia". Bab ini terdiri atas 3 subbab, yaitu: (1) Semangat dan Komitmen Sumpah Pemuda bagi Bangsa Indonesia, (2) Semangat Kekeluargaan dan Gotong Royong sebagai Bentuk Kerjasama dalam Masyarakat yang Beragam dalam Bingkai Bhinneka Tunggal Ika, dan (3) Membiasakan Kerjasama dan Kehidupan Bermasyarakat sebagai Perwujudan Semangat dan Komitmen Sumpah Pemuda. Bab VII tentang "Bersatu Kita Teguh", yang terdiri atas tiga subbab, yaitu (1) Unsur-unsur Negara Kesatuan Republik Indonesia, (2) Arti Penting Semangat Persatuan dan Kesatuan untuk Memperkuat dan Memperkokoh NKRI, dan (3) Memperkuat Semangat Persatuan dan Kesatuan yang Mencerminkan Komitmen terhadap Keutuhan Nasional. Berdasarkan hasil analisis diperoleh data bahwa muatan nilai-nilai karakter yang terkandung pada buku siswa mata pelajaran PPKn SMP Kelas VIII diwujudkan dalam subbagian yang ada pada buku yaitu bagian pendahuluan, bagian inti, dan bagian penutup. Bagian pendahuluan terdiri dari kalimat motivasi dan ilustrasi gambar serta tujuan dan ruang lingkup pembelajaran. Bagian inti terdiri atas uraian materi pelajaran, tugas individu, dan tugas kelompok. Bagian penutup terdiri dari refleksi, uji kompetensi, penilaian afektif, dan praktik kewarganegaraan. Hasil analisis Buku Siswa PPKn Kelas VIII yang bermuatan nilai-nilai karakter disajikan dalam materi setiap bab secara eksplisit.

Hasil penelitian menunjukkan bahwa muatan nilai karakter pada bagian 
pendahuluan meliputi: (1) kalimat motivasi, seperti "ayo hidup berPancasila”, "ayo sadar konstitusi”, “ayo tingkatkan kedisiplinan", "ayo bangga menjadi bangsa Indonesia", "ayo kita bersahabat dan bersaudara", "ayo menjadi pemuda yang cerdas bersatu", "Ayo bersatu untuk keutuhan bangsa". Dari ketujuh kalimat motivasi yang disajikan dalam tujuh bab dalam buku ajar terkandung nilai-nilai karakter seperti religius, peduli sosial, cinta tanah air, demokrasi, kedisiplinan, semangat kebangsaan, bersahabat/komunikatif, cinta damai, peduli sosial, gotong royong; dan (2) ilustrasi gambar, setiap ilustrasi gambar yang disajikan mengandung nilai-nilai karakter di dalamnya, seperti gambar perilaku saling menghormati, tolong-menolong, melestarikan produk dalam negeri, musyawarah, kerja bakti, kebersamaan antarmasyarakat, suasana belajar dalam kelas, perjuangan merebut kemerdekaan, koperasi sekolah, piket kelas, monumen Pancasila sakti bukti sejarah pemberontakan G30s/PKI, Negara Persatuan menyatukan perbedaan bangsa Indonesia dalam wadah NKRI. Dari berbagai uraian gambar tersebut mengandung makna nilai karakter toleransi, cinta tanah air, demokrasi, peduli lingkungan, peduli sosial, menghargai prestasi, semangat kebangsaan, kemandirian, dan nasionalis.

Pada bagian inti nilai-nilai karakter Kebangsaan diuraikan dalam bagian materi pelajaran, tugas individu, dan tugas kelompok. Dalam materi pelajaran secara eksplisit nilai-nilai karakter tersebar dalam tujuh bab, masing-masing bab diuraikan dalam subbab, yaitu pada bab I tentang "Merajut manusia dan masyarakat berdasarkan Pancasila" nilai karakter yang disampaikan meliputi religius, peduli sosial, dan demokratis. Pada bab II tentang "Menyemai kesadaran konstitusi dalam kehidupan bernegara", nilai karakter yang dikembangkan adalah disiplin dan cinta damai. Pada bab II tentang "Disiplin itu indah", muatan nilai karakter yang disampaikan adalah disiplin dan demokratis. Pada bab IV tentang "Menjelajah masyarakat Indonesia", mengandung muatan karakter toleransi, bersahabat/komunikatif, dan cinta damai. Pada bab V tentang "Kita semua sederajat dan bersaudara", nilai karakter yang dikembangkan adalah toleransi, cinta damai, dan peduli sosial. Pada bab VI tentang "Pemuda penentu masa depan Indonesia", nilai karakter yang ditanamkan adalah semangat kebangsaan dan cinta tanah air. Pada bab VII tentang "Bersatu kita teguh", mengandung nilai karakter cinta damai dan peduli lingkungan. Selain dalam materi pelajaran, nilai karakter pada bagian inti ditanamkan melalui tugas individu dan tugas kelompok, dari kedua tugas tersebut muatan nilai karakter yang ditanamkan adalah kerja keras, kreatif, gemar membaca, mandiri, rasa ingin tahu, menghargai prestasi, dan tanggung jawab.

Pada bagian penutup terdiri atas refleksi, uji kompetensi, penilaian afektif, dan praktik kewarganegaraan. Dari kegiatan refleksi dan praktik kewarganegaraan nilai karakter yang ditanamkan adalah rasa ingin tahu dan kreatif. Sedangkan pada bagian uji kompetensi nilai karakter yang ditanamkan adalah nilai gemar membaca dan tanggung jawab. Pada penilaian afektif nilai karakter yang ditanamkan adalah religius, jujur, toleransi, disiplin, kerja keras, kreatif, mandiri, demokratis, cinta tanah air, integritas, bershabat/komunikatif, gemar membaca, dan tanggung jawab.

\section{Pembahasan}

Berdasarkan hasil analisis buku siswa mata pelajaran PPKn kelas VIII SMP kurikulum 2013 materi yang terdapat pada buku ini mengandung delapan belas nilai karakter bangsa berdasarkan pedoman pengembangan pendidikan budaya dan karakter bangsa (Kemendiknas, 2010). Delapan belas ini 
tersebar dalam berbagai aspek yaitu: (1) materi yang disesuaikan dari Kompetensi Inti dan Kompetensi Dasar pada kurikulum 2013 yang dibagi pada Bab I, Bab II, Bab III, Bab IV, Bab V, Bab VI, Bab VII; (2) aktivitas siswa berwujud mencari informasi, membaca wacana, mengamati sebuah perilaku, praktik kewarganegaraan; dan (3) penilaian yang meliputi refleksi, tugas kelompok, uji kompetensi, dan program remidial.

Dari ketiga aspek di atas jika dianalisis dengan teori dari Bank and Bank (1997), maka strategi integrasi nilai-nilai karakter dalam buku teks telah memenuhi lima kriteria (1) dilakukan melalui integrasi konten, yaitu materi yang disajikan dalam buku teks telah mengilustrasikan nilai karakter, baik dalam bentuk konsep, prinsip, fakta, maupun teori mulai dari Bab I sampai dengan Bab VII. (2) Konstruk pengetahuan, (3) pengurangan prasangka, (4) pedagogik yang setara, (5) pemberdayaan budaya sekolah, dalam buku teks diintegrasikan dalam bentuk aktivitas siswa, misalnya membaca wacana, mengamati sebuah perilaku, praktek kewarganegaraan. Selain aktivitas siswa juga dikembangkan dalam bentuk penilaian, misalnya refleksi, tugas kelompok, uji kompetensi, dan program remedial.

Secara umum muatan nilai karakter diwujudkan secara eksplisit dan implisit, secara eksplisit terdapat pada tiga bagian yaitu bagian pendahuluan, bagian inti, dan bagian penutup. Pada bagian pendahuluan terdiri dari kalimat motivasi, ilustrasi gambar serta tujuan dan ruang lingkup pembelajaran, dari bagian pendahuluan ini muatan nilai karakter yang dikembangkan adalah religius, peduli sosial, demokratis, cinta tanah air, rasa ingin tahu, dan kerja keras.

Bagian inti terdiri atas uraian materi pelajaran, tugas individu, dan tugas kelompok, nilai yang dikembangkan pada bagian inti adalah toleransi, jujur, disiplin, kreatif, mandiri, semangat kebangsaan, cinta tanah air, cinta damai, gemar membaca, peduli lingkungan, peduli sosial, dan tanggung jawab. Pada bagian inti pengintegrasian nilai-nilai karakter dilakukan melalui metode pendidikan karakter. Syamsul Kurniawan (2014: 57) mengatakan metode yang yang biasanya dipraktikkan di sekolah adalah metode ceramah, yaitu penyampaian materi pembelajaran yang telah tersaji dalam buku teks kepada peserta didik, metode latihan dan pemberian tugas, dalam buku teks di sajikan dalam bentuk tugas individu dan tugas kelompok. Dari berbagai metode tersebut dipilih dan digunakan secara variasi dengan mempertimbangkan tujuan dan materi pembelajaran, serta kemampuan pendidik.

Bagian penutup terdiri atas refleksi, uji kompetensi, penilaian afektif, dan praktik kewarganegaraan, pada bagian penutup nilai karakter yang dikembangkan tanggung jawab, mandiri, dan jujur. Pada bagian ini nilai karakter yang lebih banyak ditekankan adalah nilai tanggung jawab. Pemberian tugas kepada peserta didik merupakan salah satu strategi dalam meningkatkan rasa tanggung jawab peserta didik. Sofan Amri, dkk (2011: 100) menjelaskan bahwa dalam meningkatkan tanggung jawab peserta didik adalah dengan pemberian tugas. Pemberian tugas tidak hanya menanamkan karakter tanggung jawab, melainkan juga nilai-nilai karakter lainnya ikut mengiringinya, yaitu nilai kebersamaan dan gotong royong (Rukiyati, dkk, 2014: 222). Dalam buku teks Pendidikan Pancasila dan Kewarganegaraan SMP Kelas VIII, telah dikembangkan nilai karakter tanggung jawab melalui tugas yang disajikan dalam bentuk refleksi, uji kompetensi, penilaian afektif, dan praktik kewarganegaraan.

Sedangkan secara implisit muatan nilai diwujudkan pada proses pembelajaran di kelas oleh guru aspek yang dikembangkan meliputi aspek kognitif, afektif, dan psikomotorik. 
Rancangan kegiatan pembelajaran yang dijabarkan pada buku teks Pendidikan Pancasila dan Kewarganegaraan SMP Kelas VIII setiap bab sudah mewujudkan nilai-nilai karakter bangsa yang ditanamkan dalam diri siswa diseluruh bagian buku teks pelajaran melalui transdisiplinaritas. Muhammad Yaumi (2014:126) menjelaskan bahwa transdisiplinaritas merupakan suatu pendekatan yang digunakan untuk mengintegrasikan dan mentransformasikan pengetahuan dari berbagai aspek.

Dalam hubungannya dengan pendidikan karakter, transformasi mengarah pada pengintegrasian kecerdasan spiritualitas ke berbagai disiplin dan aktivitas lainnya. Misalnya pada proses pembelajaran, aktivitas siswa diwujudkan dalam bentuk diskusi, kerja kelompok, dan tugas individu. Aktivitas tersebut akan menumbuhkan nilai karakter komunikatif, toleransi, menghargai prestasi, tanggung jawab, dan mandiri.

\section{PENUTUP}

Penanaman pendidikan karakter di sekolah merupakan strategi yang tepat dalam membangun karakter generasi bangsa Indonesia. Salah satu strategi yang dapat dilakukan adalah melalui integrasi nilai-nilai karakter dalam buku teks. Proses pengintegrasian nilai-nilai karakter pada buku teks Pendidikan Pancasila dan Kewarganegaraan SMP Kelas VIII terdapat dalam bagian pendahuluan terdiri dari kalimat motivasi, ilustrasi gambar, bagian inti terdiri dari uraian materi pelajaran, tugas individu, dan tugas kelompok, serta bagian penutup terdiri dari terdiri dari refleksi, uji kompetensi, penilaian afektif, dan praktik kewarganegaraan.

\section{UCAPAN TERIMA KASIH}

Dengan dimuatnya tulisan ini dalam Jurnal Pendidikan Karakter edisi ini, penulis mengucapkan terima kasih kepada Dr. Marzuki, M. Ag. Selaku
Ketua Dewan Redaksi Jurnal Pendidikan Karakter yang menerima dan telah banyak memberikan masukan dan arahan demi terselesaikannya tulisan ini. Ucapan terima kasih juga disampaikan kepada semua pihak yang telah membantu demi selesainya tulisan ini hingga dimuat dalam edisi sekarang.

\section{DAFTAR PUSTAKA}

Amri, Sofan dkk. 2011. Implementasi pendidikan karakter dalam pembelajaran. Jakarta: Prestasi Pustaka.

Bank, James A. \& Bank, Cherry A. 1997. Multicultural Education: issue and perspectives. Boston: Allyn and Bacon.

Budhiman, Arie. 2017. Gerakan Penguatan Pendidikan Karakter. Jakarta: Kemendikbud.

Howard, R. W., et al. 2014. Politics of character education. Educational policy, (18), 188-215.

Kementrian Pendidikan dan Kebudayaan Republik Indonesia. 2017. Konsep dan pedoman penguatan pendidikan karakter. Jakarta: Kemendikbud.

Kementrian Pendidikan Nasional. 2010. Pengembangan pendidikan budaya dan karakter bangsa. Jakarta: Kemendiknas.

Krippendorff, Klaus. 2004. Content analysis an introduction to its methodology. London: International Education and Professional Publisher.

Kurniawan, Syamsul. 2014. Pendidikan karakter konsepsi \& implementasinya secara terpadu di lingkungan keluarga, sekolah, perguruan tinggi, \& masyarakat. Yokyakarta: Ar-Ruzz Media. 
Lickona, T. 1991. Educating for character: how our school can teach respect and responsibility. New York, Toronto, London, Sydney, Aucland: Bantam Books.

Mardikarini, Sasi dan Suwarjo. 2016. Analisis muatan nilai-nilai karakter pada buku teks kurikulum 2013 pegangan guru dan pegangan siswa. Jurnal Pendidikan Karakter, (6), 261-274.

Marzuki. 2012. Pengintegrasian pendidikan karakter dalam pembelajaran di sekolah. Jurnal Pendidikan Karakter, (2), 33-44.

Normawati. 2015. Nilai pendidikan karakter dalam buku teks pelajaran bahasa Indonesia SMP di Daerah Istimewa Yogyakarta. Jurnal Pendidikan Karakter, (5), 48-69.

Peraturan Menteri Pendidikan Nasional Nomor 11 Tahun 2005 tentang Buku Teks Pelajaran.

Rukiyati, Y. Ch. Nany Sutarini, P. Priyoyuwono. 2014. Penanaman Nilai Karakter dan Kerja Sama Terintegrasi dalam Perkuliahan Ilmu Pendidikan. Jurnal Pendidikan Karakter, (2), 213-224.

Silay, Nur. 2014. Another type of character education: citizenship Education. International Journal of Education, (6), 1-10.

Yaumi, Muhammad. 2014. Pendidikan karakter landasan, pilar \& implementasi. Jakarta: Prenadamedia Group. 